UDC 632.935.7:632.772"2017"

Original research paper

doi: 10.5937/AASer1947071M

Acta Agriculturae Serbica, Vol. XXIV, 47(2019); 71-81

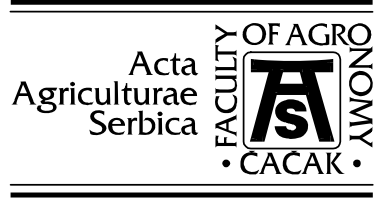

\title{
Efficiency of different types of traps in mass trapping Drosophila suzukii (Diptera, Drosophilidae) in raspberry plantings
}

\author{
Miloš Marjanović, Snežana Tanasković \\ University of Kragujevac, Faculty of Agronomy in Čačak, Cara Dušana 34, \\ 32000 Čačak, Serbia \\ Corresponding author: stanasko@kg.ac.rs
}

\begin{abstract}
Drosophila suzukii (Matsumura, 1931) is an invasive oligophagous pest native to southeastern Asia. The first documented report of this pest in Serbia was in 2014. The insect is a pest of healthy and physiologically mature (ripening) soft fruits. The aim of the study was to determine the efficiency of different types of baited traps in mass trapping specimens of this species in raspberry plantings. Five types of blends (attractants) were used for mass trapping. The experiment was set up on May $27^{\text {th }}$, 2017. Inspection and sample collections were carried out at 7-10 day intervals from June $4^{\text {th }}$ to July $31^{\text {st }}, 2017$.

Based on the analysed field data, we confirmed that standard trap $\mathrm{S}$ was the most efficient, with 8099 specimens caught in the experimental period. The number of caught specimens decreased in the deployed traps, as follows: trap T4 (695), trap T3 (682), trap T2 (643), and trap T1 (482) as the least efficient. Statistical analyses showed very significant differences between the standard trap and trap T1, and significant differences between the standard trap and the other trap types in the average number of caught specimens. No significant differences in trapping were found between the other trap types.
\end{abstract}

Keywords: Drosophila suzukii, trap, efficiency, raspberry. 


\section{Introduction}

The spotted wing drosophila (SWD), Drosophila suzukii (Matsumura, 1931) (Diptera, Drosophilidae) is an invasive oligophagous pest native to southeastern Asia (Asplen et al., 2015). The first report in Europe came in 2009 from Spain, France and Italy (Calabria et al., 2012). Ecological plasticity and a wide range of host plants enabled survival and spread in the territory of introduction (Zerulla et al., 2015). European countries, such as Italy (2009), Spain (2010) and France (2010), have established pest monitoring and control programmes (Cini et al., 2012).

The first documented and confirmed report of SWD presence in Serbia was in 2014 (Toševski et al., 2014). The species was probably introduced to Serbia through fresh fruit imports at the Horgoš border crossing. In Serbia, SWD is a very important pest of small fruits, primarily raspberry (Toševski et al., 2014), as still one threat in this production behind newer identified (Tanasković and Milenković, 2009). The harmful effects of this insect are observed during purchase or later during proccessing, and this is the main reason for justified concerns of raspberry producers, purchasers and processors.

This insect is on the EPPO A2 (EPPO, 2011) quarantine list, which requires mandatory surveillance for early detection and monitoring of pest populations, given the economically important damages caused to the host plants' healthy and ripening (mature) fruits. The main difference between this insect and other fruit flies is that SWG lays eggs in healthy fruits in the ripening phase (Pajač and Barić, 2010) by a large serrated ovipositor. Infested fruits are susceptible to infection by rot pathogens (Hauser et. al., 2011), and within a few days after infection fruits and the entire crop can completely decay.

Setting up traps is the only way to record the presence of pests in fruit and vine orchards, as well as to implement population number control measures (EPPO, 2010). Regular monitoring in orchards is necessary to keep population numbers below the economic threshold (www.pisvojvodina.com).

The aim of this study was to determine the pest presence and efficiency of traps i.e. volatile attractants according to the number of specimens caught. Based on the obtained results, the most efficient trap will be recommended for deployment in different types of orchards for mass trapping of SWD and to decrease population numbers.

\section{Material and method}

\section{Field experimental design}

The trail was set up at the Gornja Kravarica locality, Lučani municipality during 2017, in a 31-year-old open-field orchard of raspberry 'Willamette', covering an area of 0.1 ha $\left(\mathrm{N} 43^{\circ} 45^{\prime} 55,4^{\prime \prime} \mathrm{E} 20^{\circ} 10^{\prime} 33,6^{\prime \prime}, 471 \mathrm{~m}\right.$ a.s.1.). 
Hand-made plastic bottle traps were used for SWD mass trapping (Figure 1). Nine round holes $4 \mathrm{~mm}$ in diameter were made in the bottle trap to allow SWD to enter. A rectangular opening was cut in the top portion of the bottle and covered with gauze to spread volatile blends (chemicals) i.e. attractants or baits.

In the experiment, five types of traps were used:

1. Trap $\mathrm{T} 1$ - an olfactory attractant mixture of $300 \mathrm{~mL}$ apple cider vinegar and 5 g dry yeast.

2. Trap T2 - an olfactory attractant mixture of $300 \mathrm{~mL}$ apple cider vinegar, 5 $\mathrm{g}$ dry yeast, and $1 \mathrm{~g}$ white sugar.

3. Trap T3 - an olfactory attractant mixture of $300 \mathrm{~mL}$ apple cider vinegar, 5 $\mathrm{g}$ dry yeast, and $1 \mathrm{~g}$ white sugar, and a red-black plastic (PVC) stripe used as a visual attractant.

4. Trap T4 - an olfactory attractant mixture of $300 \mathrm{~mL}$ apple cider vinegar, 5 $\mathrm{g}$ dry yeast, and $1 \mathrm{~g}$ white sugar, and a yellow plastic (PVC) stripe used as a visual attractant.

5. Trap $\mathrm{S}-$ an olfactory attractant mixture of $150 \mathrm{~mL}$ red wine and $150 \mathrm{~mL}$ apple cider vinegar.

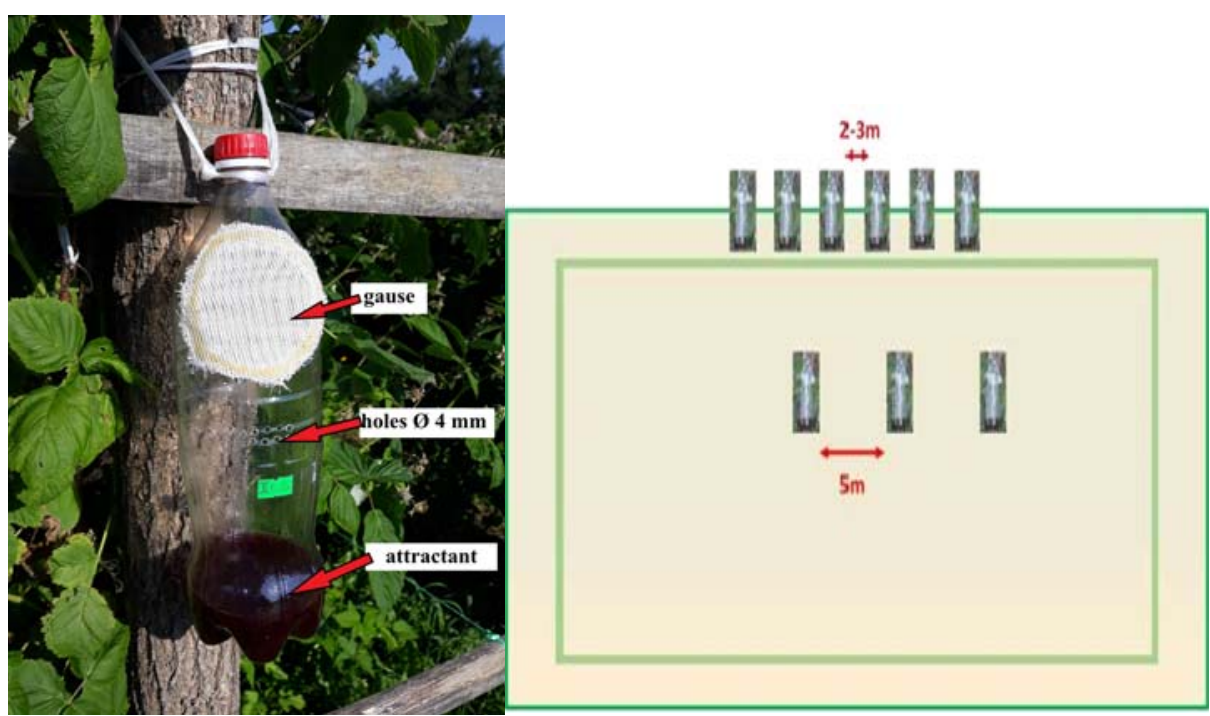

Figure 1. A hand-made trap used for D. suzukii mass trapping (photo: M. Marjanović and PISS)

A small drop of dish soap was added as a surfactant to each bait to increase SWD capture.

The trail was set up on May $27^{\text {th }}, 2017$. The raspberry planting was at the phenological growth stage BBCH $73-30 \%$ of fruits formed (Meier, 2018). 
Field inspectione were performed at 7-10 day intervals, i.e. on June $4^{\text {th }}, 12^{\text {th }}$, $22^{\text {th }}$, and July $2^{\text {nd }}, 11^{\text {th }}$ and $31^{\text {st }}, 2017$. During the inspection, specimens were filtered and transferred into plastic self-lock tubes. After sample collection, the tubes were carried to the laboratory at the Faculty of Agronomy, where insects were identified and specimens counted for further analyses.

\section{Data analyses}

Adults were identified by a Leica M 125 binocular, equipped with LAS software.

Statistical analyses were performed by one- and two-sample $t$ tests at $\mathrm{p}<0.05$ using GenStat $12^{\text {th }}$ Edition, and $\overline{\mathrm{x}} \mathrm{t}$ test single sample at $\mathrm{p}<0.05$ using STATISTICA 7 StatSoft.

\section{Results and discussion}

The highest efficiency in the first examination was shown by attractant $\mathrm{S}$, with an average catch of 53.85 adults per trap, followed by the attractants T4, T2, and $\mathrm{T} 1$ as the least effective (Figure 2).

In the second examination, the highest efficacy was found for attractant $\mathrm{S}$, as in the first inspection, whereas the second highest efficacy was shown by attractant T3, unlike the previous examination (Figure 2).

Unlike the first two inspections, the highest efficiency in the third inspection was shown by attractant T3. However, the other attractants did not show significantly lower efficiency, and their average catches ranged from 31.00 to 36.67 adults (Figure 2).

The fourth inspection differed from the rest in having the extremely low efficiency of the four types of attractants T1, T2, T3 and T4. The attractant efficiency of S was very high, as in the first two inspections (Figure 3).

The fifth inspection was conducted on the July, 11th. As in the fourth inspection, the 4 types of attractants T1, T2, T3 and T4 showed a very low efficiency. The efficiency of attractant $\mathrm{S}$ was high i.e. on average 43.21 adults were caught (Figure 3 ). 


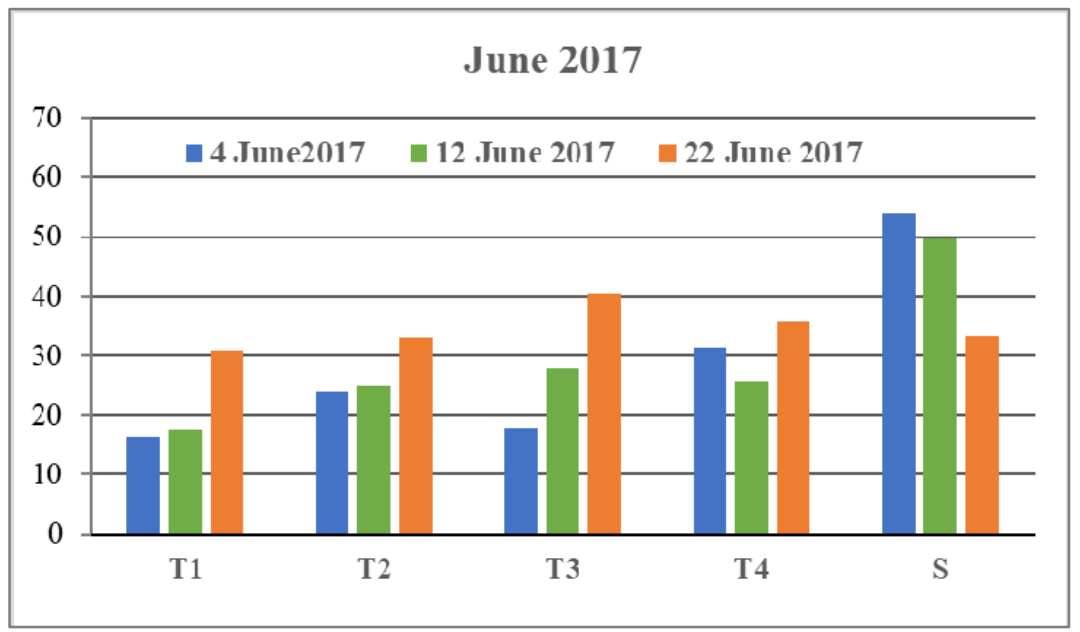

Figure 2. Number of specimens caught per trap in June

The last inspection was carried out on 31 July. During the period from 11 to 31 July, extremely high air temperatures caused reduced pest activity and a decrease in pest abundance (Figure 3). Very low efficiency of all types of attractants was reported. But again, attractant $\mathrm{S}$ stood out as having the highest efficiency.

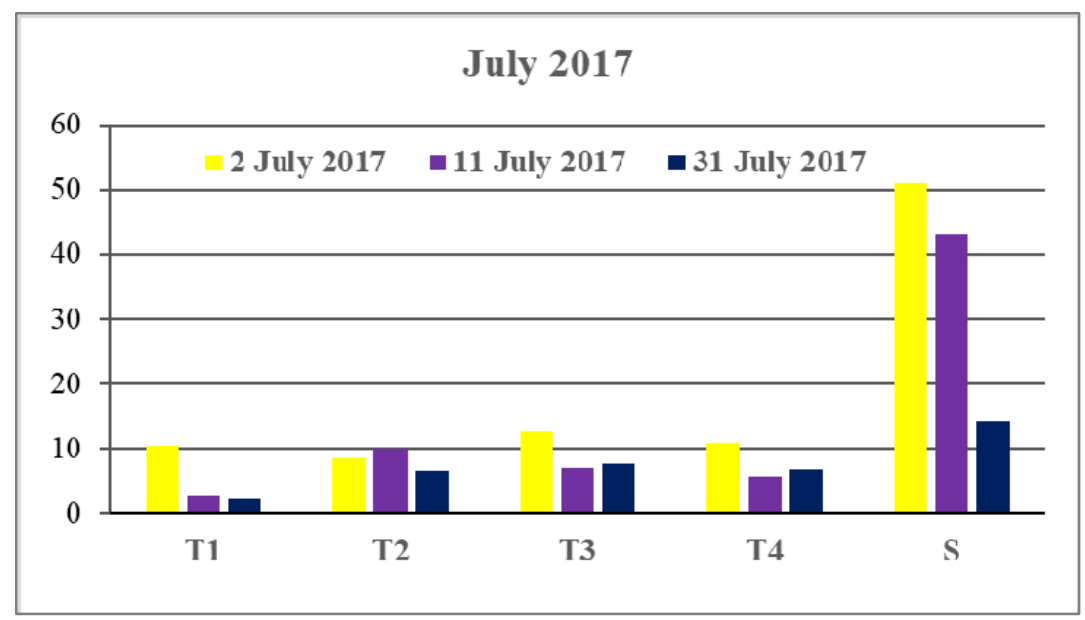

Figure 3. Number of specimens caught per trap in July

The low trap efficiency, i.e. the low number of caught specimens was probably the consequence of the end of the raspberry harvest (around 20 July 
2017). Also, extremely high air temperatures over $35^{\circ} \mathrm{C}$ were recorded during this period, and contributed to the decline in SWD numbers in the planting.

Monitoring results of the total and average numbers of specimens caught per bait/trap are shown in Table 1 .

Table 1. Total and average numbers of specimens caught per trap in the trial

\begin{tabular}{|c|c|c|c|}
\hline \multirow{2}{*}{ Trap type } & \multicolumn{2}{|c|}{ Total number } & $\begin{array}{c}\text { Average number of } \\
\text { specimens caught per } \\
\text { trap } \pm \text { Sd }\end{array}$ \\
\cline { 2 - 3 } & $\begin{array}{c}\text { Number of caught } \\
\text { specimens }\end{array}$ & $\begin{array}{c}\text { Number of } \\
\text { installed traps }\end{array}$ & $80.33 \pm 59.08$ \\
\hline T1 & 482 & 6 & $107.16 \pm 59.92$ \\
\hline T2 & 643 & 6 & $113.67 \pm 71.57$ \\
\hline T3 & 682 & 6 & $115.83 \pm 72.26$ \\
\hline T4 & 695 & 6 & $245.42 \pm 53.11$ \\
\hline S & 8099 & 33 & \\
\hline
\end{tabular}

The best results i.e. the highest number (8 099) of specimens caught in the experimental period were found in trap S, followed by T4 (695), T3 (682), T2 (643) and T1 (482). Table 1 and Figure 2 give the average and total numbers of specimens caught per trap.

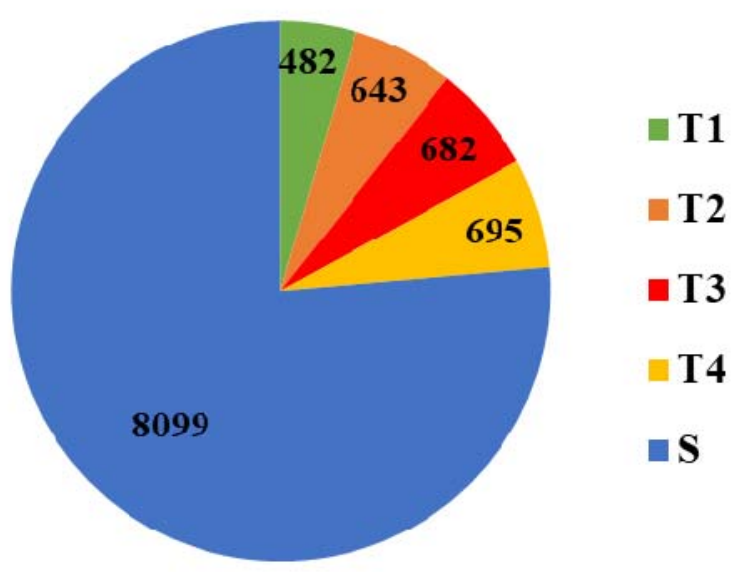

Figure 4. Total number of specimens caught per trap 
The red wine + apple cider vinegar attractant was the best bait during the mass trapping of SWD in this trial. Also, in this research, T4, T3 and T2 baits were equally attractive, and the lowest attractiveness was determined for T1. These results are opposite to Kovačević (2018) results. Her results indicate that T1 bait (apple cider + dry yeast) was highly efficient, subsequent to T4. This could be explained by the fact that SWD in nochoice conditions flew to T1, because this type of blends (apple cider + dry yeast) was not installed.

Based on the obtained results, the highest number of caught specimens was recorded between the end of May and the beginning of June (Table 2) in all trap types, and this overlapped with the beginning of the fruit ripening phase. Later in the growing season, the number of caught specimens decreased, which was in agreement with the results of Kovačević (2018) and Stojković Jovanović (2018). Also, this is completely consistent with the results of Wang et al. (2016). At 28 locations in California, these authors determined that the first peak numbers occurred at the same time as the beginning of fruit ripening, and the second later in the growing season on spontaneous plants (weeds). This implies that SWD migrates from orchards, and suggests that adjacent biotopes and biocenoses are not only alternative host sources but also very dangerous reservoirs of pest populations in the next spring for orchards and plantings (Briem et al., 2016).

The statistical analysis of the obtained data is shown in Table 2.

Table 2. The mean number of caught Drosophila suzukii specimens $(\overline{\mathrm{x}} \pm S d)$ per trap across inspections

\begin{tabular}{|c|c|c|c|c|c|c|}
\hline \multirow{2}{*}{ है } & \multicolumn{6}{|c|}{ Date of inspection } \\
\hline & 4 June & 12 June & 22 June & 2 July & 11 July & 31 July \\
\hline $\mathrm{T} 1$ & $\begin{array}{c}16.17 \pm \\
9.82 \\
\end{array}$ & $\begin{array}{c}17.67 \pm \\
10.58 \\
\end{array}$ & $\begin{array}{l}31.0 \pm \\
34.22 \\
\end{array}$ & $\begin{array}{l}10.5 \pm \\
11.76 \\
\end{array}$ & $\begin{array}{c}2.67 \pm \\
3.14 \\
\end{array}$ & $\begin{array}{c}2.33 \pm \\
3.09 \\
\end{array}$ \\
\hline $\mathrm{T} 2$ & $\begin{array}{c}24, .7 \pm \\
12.02\end{array}$ & $\begin{array}{c}25.00 \pm \\
12.58\end{array}$ & $\begin{array}{c}33.00 \pm \\
49.50\end{array}$ & $\begin{array}{c}8.50 \pm \\
8.10\end{array}$ & $\begin{array}{c}10.00 \pm \\
21.05\end{array}$ & $\begin{array}{c}6.50 \pm \\
7.07\end{array}$ \\
\hline $\mathrm{T} 3$ & $\begin{array}{l}18.0 \pm \\
11.46\end{array}$ & $\begin{array}{c}27,83 \pm \\
14,54\end{array}$ & $\begin{array}{l}40.5 \pm \\
39.35\end{array}$ & $\begin{array}{c}12.67 \pm \\
10.21\end{array}$ & $\begin{array}{l}7.00 \pm \\
12.18\end{array}$ & $\begin{array}{c}7.67 \pm \\
4.07\end{array}$ \\
\hline $\mathrm{T} 4$ & $\begin{array}{c}31.33 \pm \\
21.93 \\
\end{array}$ & $\begin{array}{c}25.67 \pm \\
16.01 \\
\end{array}$ & $\begin{array}{c}35.67 \pm \\
45.33\end{array}$ & $\begin{array}{c}10.83 \pm \\
9.25 \\
\end{array}$ & $\begin{array}{c}5.67 \pm \\
8.69 \\
\end{array}$ & $\begin{array}{c}6.67 \pm \\
12.71 \\
\end{array}$ \\
\hline $\mathrm{S}$ & $\begin{array}{c}53.85 \pm \\
54.84 \\
\end{array}$ & $\begin{array}{c}49.64 \pm \\
50.16 \\
\end{array}$ & $\begin{array}{c}33.42 \pm \\
32.66\end{array}$ & $\begin{array}{c}51.09 \pm \\
64.07 \\
\end{array}$ & $\begin{array}{c}43.21 \pm \\
69.25 \\
\end{array}$ & $\begin{array}{c}14.21 \pm \\
17.78 \\
\end{array}$ \\
\hline
\end{tabular}

The statistical analyses indicate very significant differences between trap $\mathrm{S}$ and trap $\mathrm{T} 1(\mathrm{~F}=1.93$ and $\mathrm{p}=0.004 * *)$. Statistical differences were found between trap $\mathrm{S}$ and the other three trap types i.e. $\mathrm{T} 2\left(\mathrm{~F}=1.87\right.$ and $\left.\mathrm{p}=0.12^{*}\right), \mathrm{T} 3(\mathrm{~F}=1.31$ and $\mathrm{p}=0.022 *)$ and $\mathrm{T} 4\left(\mathrm{~F}=1.29\right.$ and $\left.\mathrm{p}=0.024^{*}\right)$. The comparison of the four trap types (T1, T2, T3 and T4) showed no statistical differences in the average 
number of specimens caught per trap. Practically, this indicates that regardless of the trap type used in SWD mass trapping, there were no significant differences in the number of specimens caught.

The statistical analysis of the average number of specimens caught per trap across inspections confirmed very significant differences between trap $\mathrm{S}$ and all other types $\left(\mathrm{t}=6.69 ; \mathrm{p}=0.0011^{* *}\right)$, indicating that trap $\mathrm{S}$ was the most efficient trap type.

The comparison of the other types of traps for the same parameter (specimens caught per trap across inspections), T1 $\left(\mathrm{t}=3.04 ; \mathrm{p}=0.0287^{*}\right), \mathrm{T} 2 \quad(\mathrm{t}=3.99$; $\left.\mathrm{p}=0.0103^{*}\right)$, T3 $\left(\mathrm{t}=3.55 ; \mathrm{p}=0.0164^{*}\right)$, and $\mathrm{T} 4\left(\mathrm{t}=3.58 ; \mathrm{p}=0.0158^{*}\right)$, showed significant differences in the average number of specimens caught per inspection for the entire experimental period.

Evidently, agroenvironmental conditions influence the number of caught specimens (Tochen et al., 2014), as confirmed in this research. An increase in the number of caught specimens of $D$. suzukii is caused by lower air temperatures, high relative humidity and lower/lack of precipitation amounts. Population declines are due to higher temperatures, lower relative humidity and different precipitation amounts. Cultural practices, such as irrigation, pruning and maintenance of intra- and inter-row spacing, play an important role in increasing SWD populations (Tochen et al., 2014).

\section{Conclusion}

Based on monitoring, field sampling and laboratory research, the following conclusions were reached:

1. The highest efficiency in the number of caught insects, except in the third inspection (22 June 2017), was shown by the trap S (red wine + apple cider vinegar).

2. A total of 8.099 specimens were trapped in trap S. Trapping efficiency decreased to T4 (695 specimens), T3 (682 specimens), T2 (643 specimens) and T1 (482 specimens).

3. The highest average number of adults in the growing season was caught by attractant S (245.42 specimens per trap), followed by the attractants T4 (115.83), T3 (113.67) and T2 (107.16). The lowest overall efficiency was shown by attractant $\mathrm{T} 1$, with an average catch of 80.33 specimens per trap.

The results suggest that the most efficient trap was the standard trap, with 8099 specimens caught (about 3.2 times more than the total catch for the other four traps). The findings indicate that attractant $\mathrm{S}$ (red wine + apple cider vinegar) can be recommended to farmers as highly efficient in mass trapping SWD in raspberry plantings. 


\section{References}

Asplen M. K., Anfora G., Biondi A., Choi D., Chu D., Daane K.M., Gibert P., Gutierrez A. P., Hoelmer K.A., Hutchison, W.D., Isaacs R., Jiang Z., Zsolt Kárpáti Z., Kimura M.T., Pascual M., Philips C. R., Plantamp C., Ponti L., Vétek G., Vogt H., Walton V.M., Yu Y., Zappalà L., Desneux N. (2015): Invasion biology of spotted wing Drosophila (Drosophila suzukii): a global perspective and future priorities. Journal of Pest Science, 88: 469-494.

Briem F., Eben A., Gross J., Voght H. (2016): An invader supported by a parasite: mistletoe berries as a host for food and reproduction of spotted wing drosophila in early spring. Journal of Pest Science, 89 (3): 749-759.

Calabria G., Máca J., Bächli G., Serra L., Pascual M. (2012): First records of the potential pest species Drosophila suzukii (Diptera: Drosophilidae) in Europe. Journal of Applied Entomology, 136; 139-147.

Cini A., Ioriatti C., Anfora G. (2012): A review of the invasion of Drosophila suzukii in Europe and a draft research agenda for integrated pest management. Bulletin of insectology, 65 (1): 149-160.

EPPO (2010): Drosophila suzukii (Diptera: Drosophilidae). Spotted wing drosophila. Preuzeto

sa http://www.eppo.int/QUARANTINE/Alert_List/insects/Drosophila_suzukii_factsheet_1 2-2010.pdf (24.01.2019).

EPPO (2011): EPPO Reporting Service. EPPO Reporting Service. Paris, France: EPPO. http://archives.eppo.org/EPPOReporting/Reporting_Archives.htm (25.01.2019).

Hauser M. (2011): A historic account of the invasion of Drosophila suzukii (Matsumura) (Diptera: Drosophilidae) in the continental United States, with remarks on the identification. Society of Chemical Industry, 67: 1352-1357.

Kovačević V. (2018): Efikasnost različitih atraktanata u izlovu Drosophila suzukii (Matsumura, 1931), Agronomski fakultet u Čačku. Završni rad: 1-74.

Meier U. (2018): Growth stages of mono- and dicotyledonous plants BBCH Monograph. pp 1-204. Julius Kühn-Institut (JKI) Quedlinburg 2018.

Pajač I., Barić B. (2010): Drosophila suzukii (Matsumura, 1931), potencijalni štetnik koštičavog voća u Hrvatskoj (2010), Pomologia Croatica, 16 (1-2): 48.

Preuzeto sa: www.pisvojvodina.com (26.01.2019).

Stojković Jovanović Lj. (2018): Brojnost izlovljenih imaga Drosophila suzukii (Matsumura, 1931) na različitim voćnim vrstama, Agronomski fakultet u Čačku. Završni rad: 1-71.

Tanasković S., Milenković S. (2009): Occurrence of Raspberry Gall Midge Lasioptera rubi Schrank (Diptera, Cecidomyiidae) in Some Raspberry Cultivars. Acta Agriculturae Serbica, 14 (28): 75-81.

Tochen S., Dalton D. T., Wiman N.G., Hamm C., Shearer P.W., Walton V.M. (2014): Temperature-related development and population parameters for Drosophila suzukii (Diptera: Drosophilidae) on cherry and blueberry. Environmental Entomology, 43 (2): 501-510.

Toševski I., Milenković S., Krstić O., Kosovac A., Jakovljević M., Mitrović M., Cvrković T., Jović J. (2014): Drosophila suzukii (Matsumura, 1931) (Diptera: Drosophilidae), a new invasive pest in Serbia. Zaštita bilja, 65 (3): 99-104.

Wang X.G., Stewart T.J., Biondi A. (2016): Population dynamics and ecology of Drosophila suzukii in Central California. Journal of Pest Science, 89: 701-712. 
Zerulla F. N., Schmidt S., Streitberger M., Zebitz C.P.W., Zelger R. (2015): On the overwintering ability of Drosophila suzukii in South Tyrol. Journal of Berry Research, $5: 41-48$. 
Acta Agriculturae Serbica, Vol. XXIV, 47(2019); 71-81

\title{
EFIKASNOST RAZLIČITIH TIPOVA KLOPKI U IZLOVU DROSOPHILA SUZUKII (DIPTERA, DROSOPHILIDAE) U ZASADU MALINE
}

\author{
Miloš Marjanović, Snežana Tanasković \\ Agronomski fakultet u Čačku, Cara Dušana 34, \\ 32000 Čačak, Srbija \\ Rezime
}

Drosophila suzukii (Matsumura, 1931) je invazivna, izrazito polifagna štetočina poreklom iz jugoistočne Azije. Prvi dokumentovan i potvrđen nalaz u Srbiji potiče iz 2014. godine. Ekonomska značajnost ove vrste posledica je njene aktivnosti, jer je štetočina fiziološki zdravog i zrelog ploda. Cilj rada je bio da se ispita efikasnost različitih atraktanata u masovnom izlovu ove nove štetne vrste u zasadu maline. Za masovno izlovljavanje imaga $D$. suzukii korišćeno je pet različitih tipova klopki. Ogled je postavljen 27. maja 2017. godine, a terenski pregledi i prikupljanje uzoraka obavljani su na svakih 7 do 10 dana, od 4. juna do 31. jula 2017. godine. Analizom prikupljenih podataka sa terena utvrđeno je da je u masovnom izlovu najefikasnija klopka u tipu S, sa izlovljenih 8099 primeraka. Po efikasnosti izlovljenih imaga slede tipovi klopki, T4 (695), T3 (682), T2 (643) i kao najmanje efikasan tip T1 (482). Statistička analiza pokazuje da se tip klopke S veoma značajno razlikuje od tipa klopke T1, dok se od ostalih tipova klopki T2, T3 i T4 značajno razlikuje po prosečnom broju izlovljenih imaga. Između ostalih tipova klopki nije bilo značajne statističke razlike u broju izlovljenih imaga.

Ključne reči: Drosophila suzukii, atraktant, klopka, efikasnost, malina. 